\title{
Taxonomy, phylogeny and biogeography of the late Famennian conodont genus Mashkovia
}

\author{
ZDZISLAW BELKA
}

Geologisch-Paläontologisches Institut, Universität Tübingen, Sigwartstr. 10, D - 72076 Tübingen, Germany.

\begin{abstract}
Mashkovia is one of the provincial conodonts which developed during late Famennian time in the cratonic regions of Russia. In this study, the taxonomy of this genus is revised, based on diagnostic characters of the $\mathrm{Pa}$ elements, such as the morphology of the anterior part of the platform, the ornamentation and the shape of the secondary keels. As a consequence, four species, including $M$. silesiensis n. sp. now discovered in Upper Silesia of southern Poland, are distinguished. The apparent absence of Mashkovia from North America, Variscan Europe, Australia and Africa cannot be simply explained by using temperature or other global climatic factors as a reason for the provincialism. Currents and/or local palaeoecologic factors were probably more important in controlling the distribution of these conodonts. J. Micropalaeontol. 17(2): 119-124, December 1998.
\end{abstract}

\section{INTRODUCTION}

This paper summarizes the present knowledge of the late Famennian conodont genus Mashkovia, which is a real rarity among the Devonian conodont elements. Up to now, only about 80 specimens of $\mathrm{Pa}$ elements of Mashkovia have been found throughout the world. The multi-element composition of its apparatus is unknown. As at present conceived, Mashkovia contains four species, three of which, M. simakovi (Gagiev, 1979), M. similis (Gagiev, 1979), and M. tamarae Kononova \& Pazuhin, 1983, are known exclusively from Russia. The fourth one, $M$. silesiensis $n$. sp., has been discovered in Upper Silesia of southern Poland (Fig. 1) and it is described herein.

\begin{tabular}{|c|c|c|c|}
\hline Species & 231 & 238 & 250 \\
\hline Bispathodus aculeatus plumulus & 1 & & \\
\hline Bispathodus costatus & 4 & 33 & \\
\hline Bispathodus stabilis & 76 & 73 & 13 \\
\hline Bispathodus ultimus & & 3 & \\
\hline 'Icriodus' raymondi & & & 2 \\
\hline Palmatolepis gracilis gracilis & 13 & 7 & 26 \\
\hline Palmatolepis gracilis expansa & & & 1 \\
\hline Palmatolepis gracilis sigmoidalis & 14 & 3 & 24 \\
\hline Palmatolepis perlobata postera & & 2 & \\
\hline Palmatolepis perlobata schindewolfi & 3 & & 5 \\
\hline Palmatolepis rugosa ampla & 10 & 1 & \\
\hline Palmatolepis rugosa rugosa & 19 & & \\
\hline Mashkovia silesiensis $\mathrm{n} . \mathrm{sp}$. & 1 & 1 & 5 \\
\hline Polygnathus communis communis & & 4 & 2 \\
\hline Polygnathus delicatulus & & & 12 \\
\hline Polygnathus experplexus & 4 & 2 & 15 \\
\hline Polygnathus homoirregularis & & 2 & \\
\hline Polygnathus margaritatus & & & 21 \\
\hline Polygnathus perplexus & & & 2 \\
\hline Polygnathus semicostatus & & & 1 \\
\hline Polygnathus subirregularis & & & 4 \\
\hline Polygnathus znepolensis & 10 & 11 & 64 \\
\hline Pseudopolygnathus brevipennatus & 4 & 2 & 2 \\
\hline Pseudopolygnathus controversus & & 1 & \\
\hline Mehlina strigosa & & & 52 \\
\hline Total & 159 & 145 & 251 \\
\hline
\end{tabular}

Table 1. Platform conodont elements recovered from the Upper Silesian borehole WB-138 at the depth of 231, 238 and $250 \mathrm{~m}$. The core samples were $c .1 \mathrm{~kg}$ in weight.

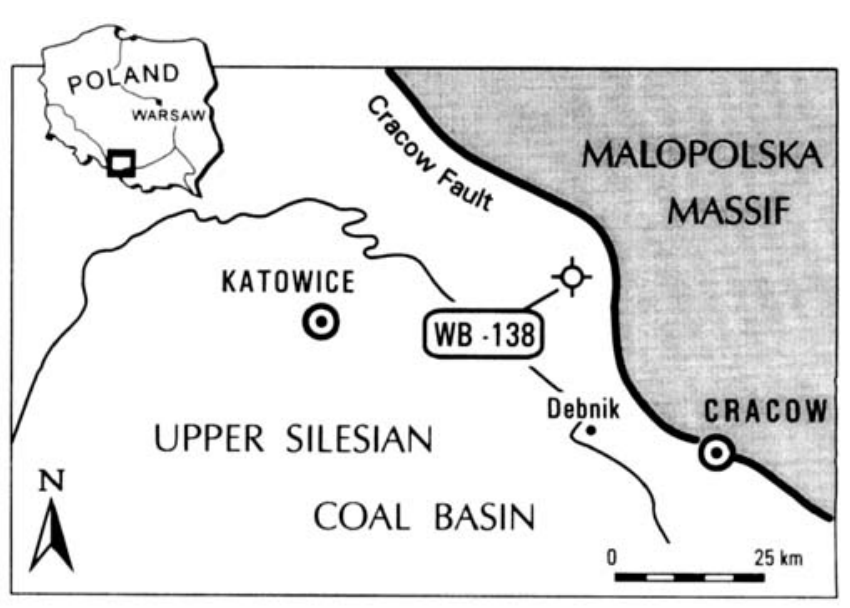

Fig. 1. Schematic map of the Cracow-Silesia region with location of the investigated borehole and the study area in southern Poland.

In Upper Silesia, the Famennian rocks are generally covered by thick Carboniferous and younger formations. A pioneering study of the Famennian conodont biostratigraphy and facies distribution was made by Narkiewicz (1978) in the subsurface, although there are some small outcrops of the Famennian carbonates in the vicinity of Debnik, $c .15 \mathrm{~km}$ west of Cracow. This was because numerous boreholes were available from the northeastern margin of the Upper Silesian Massif where the Palaeozoic and Triassic were drilled extensively in search for lead- and zinc-bearing deposits. The Devonian faunas of the Upper Silesian Massif, including conodonts, are currently of interest as they are expected to provide important evidence of the provenance and displacement history of this crustal block (Belka, 1995).

The specimens of Mashkovia silesiensis $\mathrm{n}$. $\mathrm{sp}$. were found in the Famennian basinal deposits pierced by the borehole WB138, which was situated at the northeastern margin of the Upper Silesian Massif, very close to the contact with the Malopolska Massif (Fig. 1). Conodont collections were made from carbonate mudstones containing large amounts of radiolarians and sponge spicules. These suspension deposits, dated as the Lower to Middle expansa Zone, are often intercalated with carbonate turbidites developed as bioclastic packstones to 


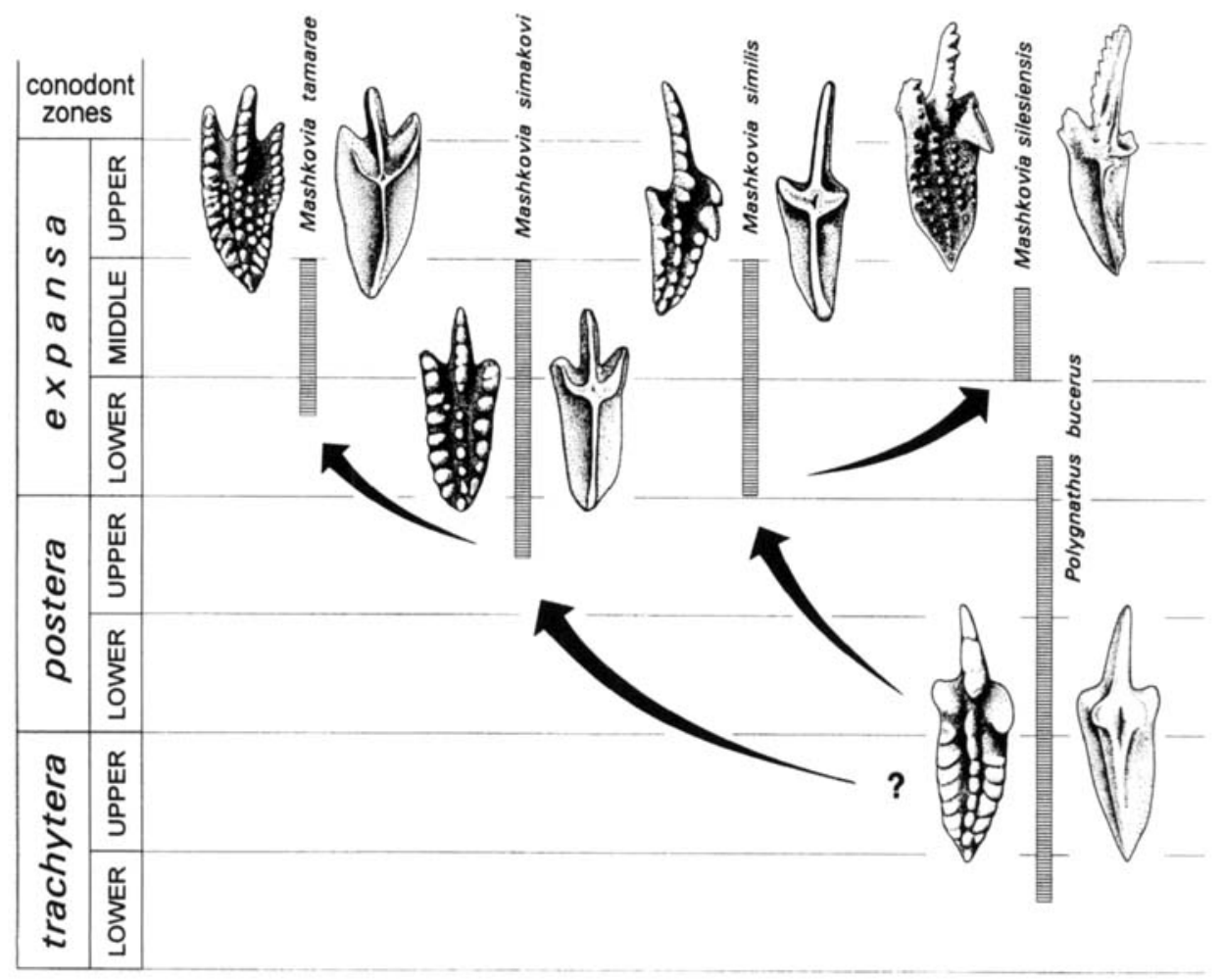

Fig. 2. Stratigraphic ranges of species of Mashkovia and the suggested evolutionary development.

grainstones (Slupeczanska, pers. comm.). The rich conodont fauna is dominated by Bispathodus and Palmatolepis, and associated with numerous representatives of Polygnathus (Table 1). The specimens of $M$. silesiensis $\mathrm{n}$. sp. were extracted from the carbonate mudstone core samples taken from depths of 231,238 and $250 \mathrm{~m}$.

\section{PHYLOGENY}

Although the multi-element composition of the Mashkovia apparatus is unknown, the character of the $\mathrm{Pa}$ elements suggests a close relation to Polygnathidae. However, it is likely that Mashkovia represents a stock, like Ancyrodella and Ancyrodelloides, which evolved directly from the Spathognathodontidae and produced $\mathrm{Pa}$ elements of similar morphology (cf. Sweet, 1988).

The suggested evolutionary development of Mashkovia and the characteristic morphologies of its species are illustrated in Fig. 2. The degree of development of the anterior platform margin and differences in morphology of the posterior platform area allow four species to be recognized. Additional morphological features useful in differentiating species of Mashkovia are the secondary keels present on the lower surface. Because of the sparsity of records of these conodonts in the world, it is not yet possible to observe the character of the interspecific evolutionary changes. The present concept of the genus, therefore, should be considered as preliminary. In contrast to the previous treatment (Aristov et al., 1983), the species Mashkovia bucera Aristov is transferred herein to the genus Polygnathus because of the character of the lower surface.
The origin of Mashkovia is uncertain. This is because data from Russian localities supporting suggested ranges of the species are not strong. It is possible, for instance, that the range of Mashkovia similis may precede that of $M$. simakovi (Fig. 2). Aristov found one broken specimen of Mashkovia (described as Mashkovia sp. nov. A) near Voronezh in Russia in the Turgenevo unit correlated with the postera Zones. The illustrated upper view of this form (in Aristov et al., 1983, pl. 2, fig. 5) shows some features characteristic for $M$. similis but because of poor preservation a final identification is equivocal.

The morphological features of $M$. similis suggests that this species evolved directly from Polygnathus bucerus and gave rise to $M$. silesiensis $\mathrm{n}$. $\mathrm{sp}$. by development of nodose ornamentation and prominent, asymmetrical fixed blades at the anterior platform margins. Later, within the Middle expansa Zone, this phyletic lineage produced much more advanced forms of the genus Tanaisognathus. $M$. simakovi appears to represent starting-points of another phyletic lineage leading to development of symmetrical, nodose platform, as in the case of $M$. tamarae. The origin of $M$. simakovi is poorly understood. As long as the earliest species of Mashkovia is uncertain, $P$. bucerus is considered as a possible ancestor (Fig. 2), but the morphological differences separating this species from $M$. simakovi are distinctive.

\section{BIOGEOGRAPHY}

The Famennian conodont genus Mashkovia is known only from a few places in the world. The records are concentrated in Russia on both sides of the Ural fold system. Representatives of 


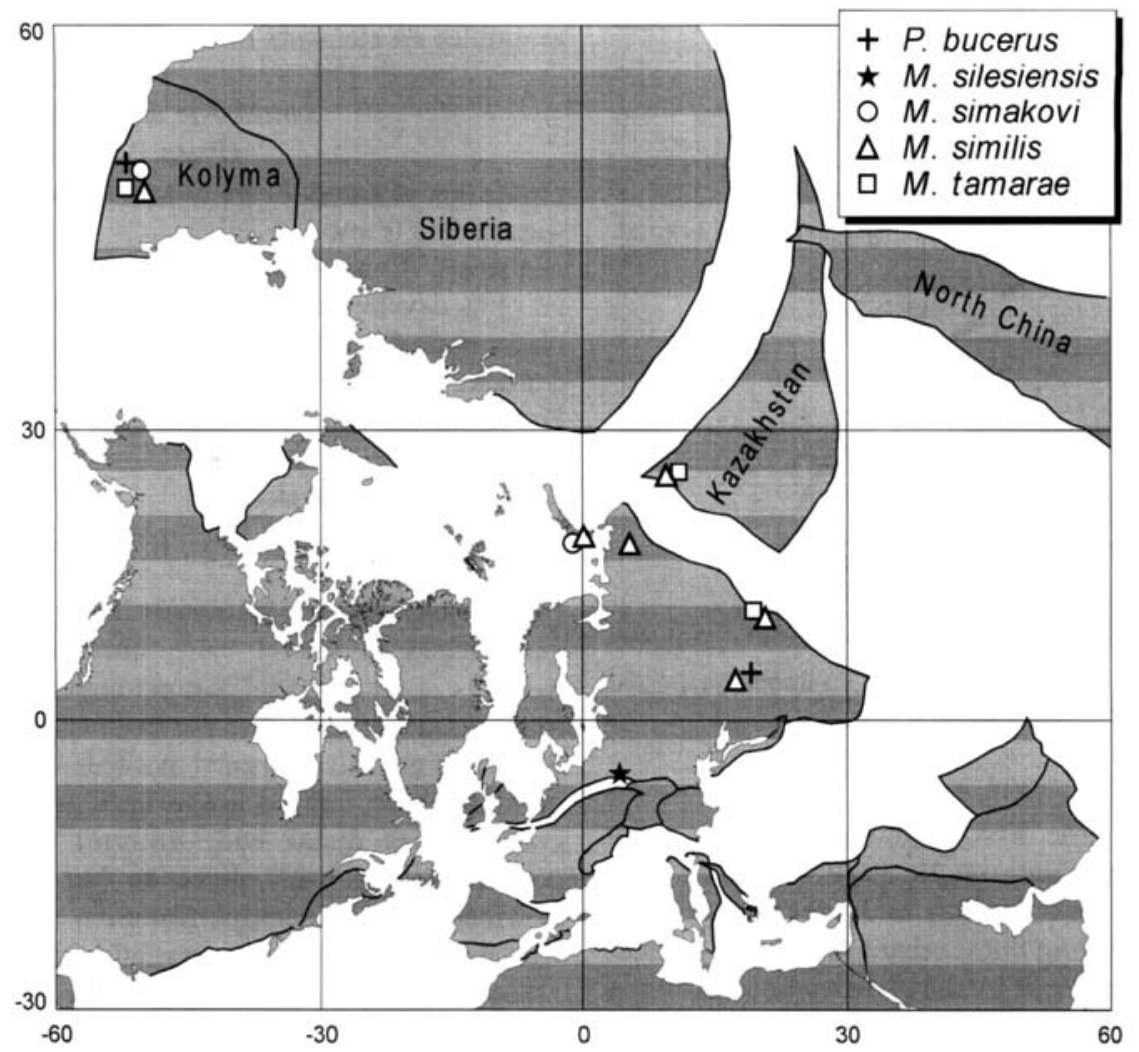

Fig. 3. Palaeogeographic distribution of Mashkovia and its ancestor Polygnathus bucerus. The palaeogeographic reconstruction for Famennian time is taken from Atlas (Version 3.2), an interactive software developed for the PC by Cambridge Paleomap Services Limited.

Mashkovia occur moreover in the Verkhoyansk region of northeastern Asia and has now been discovered in Upper Silesia of southern Poland. Plotting the Mashkovia occurrences on a palaeogeographical map for Famennian time (Fig. 3) shows that these conodonts were primarily present on both sides of the narrow oceanic realm that persisted between the North American (Laurentia) and East European (Baltica) plates, on the one side, and the Kazakhstan, Siberia and Kolyma, on the other. The single occurrence in the southern hemisphere is that from the Upper Silesian Massif located close to the southern margin of Baltica.

Although the seven currently known records of Mashkovia do not certainly reveal its entire geographic distribution, some important preliminary conclusions can be made. The observed distribution pattern of Mashkovia does not reflect the amount of work done in various parts of the world. It is also not a result of insufficient sampling or small sample size. Very rich conodont faunas of the expansa Zone are known and widely distributed in North America, Variscan Europe, Australia and on the African continent (e.g. Ziegler, 1962; Glenister \& Klapper, 1966; Sandberg \& Ziegler, 1979; Perri \& Spalletta, 1991; Savoy \& Harris, 1993). These faunas contain neither Mashkovia nor other late Famennian elements, such as Tanaisognathus and Omolonognathus, that are commonly associated with it. It seems, therefore, that the apparent absence of Mashkovia from North America, Variscan Europe, Australia, and Africa is a real restriction in geographic distribution of these conodonts. This pattern, however, cannot be simply explained by using temperature or other global climatic factors as a reason for the provincialism. Currents and/or local palaeoecologic factors were probably more important in controlling the distribution of Mashkovia.

To some extent the occurrence of Mashkovia in Upper Silesia may look surprising but on the other hand, it is possible that this fact provides important constraints on plate tectonic evolution of the foreland of the eastern Variscides. Current theory holds that this region is built up by a mosaic of crustal blocks characterized by varied crustal thicknesses and by a different tectono-thermal and sedimentary development. The segments now amalgamated between the Variscan deformation front and the East European Platform are usually interpreted as Gondwana-derived terranes. In southern Poland, these are the Upper Silesian Massif, the Malopolska Massif and the Lysogory unit (Fig. 4). In the areas situated eastwards of Upper Silesia, including the marginal part of the East European Platform (i.e. Baltica), Mashkovia has not been found in the high-diversity Famennian conodont faunas (e.g. Matyja, 1993; Szulczewski et al., 1996). The fauna of the Upper Silesian Massif (Fig. 4), however, contains in addition to Mashkovia other 'exotic' conodonts. In a section exposed near Debnik, c. $20 \mathrm{~km}$ to the south of the borehole WB-138 (Fig. 1), Balinski (1995) recently found conodont elements of the species Omolonognathus transformis Gagiev known hitherto only from Kolyma (Gagiev, 1979).

The fact that the 'exotic' conodont elements are present only on the outermost terrane with respect to Baltica can be 


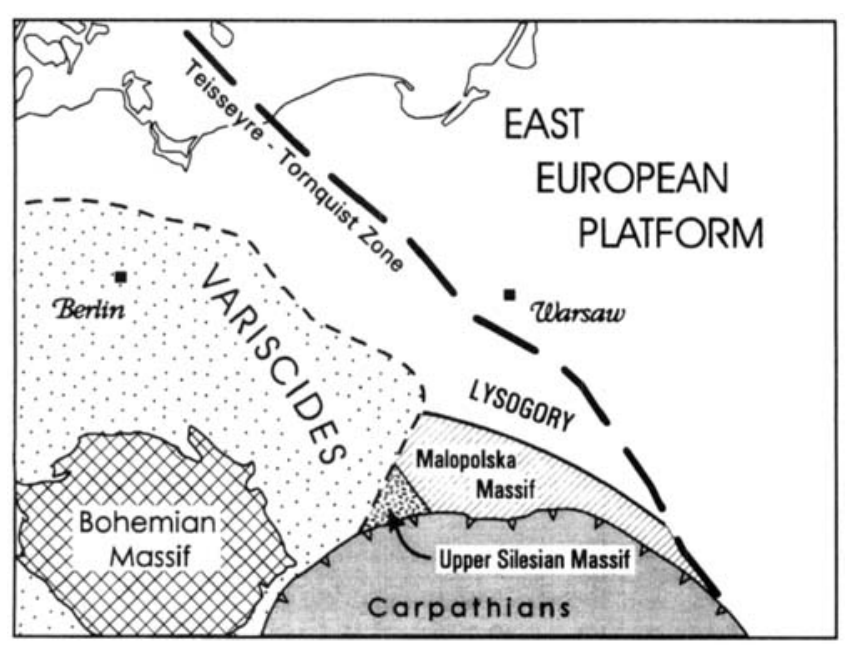

Fig. 4. Simplified structural map of central Europe. Conodonts reported here occur within the Upper Silesian Massif.

explained in two ways. The first explanation is that the Mashkovia and Omolonognathus might have preferred seas covered plate margins as their habitat and they migrated to the Upper Silesian Massif along the southern margin of Baltica. This possibility is well constrained by the plate tectonic locations of the known records of Mashkovia (Fig. 3). The second explanation is that the Upper Silesian Massif was positioned much further eastwards during Famennian time and then displaced along the edge of Baltica to reach its present-day position. Such a scenario is favoured by Lewandowski (1995) based on palaeomagnetic data. The accretionary history of the Upper Silesian Massif, however, is still a matter of controversy because the palaeomagnetic data from the Palaeozoic of southern Poland do not rule out a more 'stationary' model with the Upper Silesian block situated in its present-day position already during Devonian times (Nawrocki, 1995).

\section{SYSTEMATIC PALAEONTOLOGY}

Figured specimens are deposited at the University of Tübingen (GPIT).

\section{Genus Mashkovia Aristov, Gagiev \& Kononova, 1983}

Type species. Pseudopolygnathus similis Gagiev, 1979

Diagnosis. Mashkovia is characterized by a carminiplanate $\mathrm{Pa}$ element with distinctly developed, asymmetrical and denticulated anterior margins; free blade is short and high; carina typically composed of small, discrete denticles or widely spaced nodes; platform bordered by strong, marginal nodes or covered with longitudinal rows of nodes; lower surface typically bears two anteriorly directed secondary keels; a basal cavity or pit is positioned where the main keel and the secondary keels meet.

Remarks. Except for $\mathrm{Pa}$ elements, no other elements of Mashkovia apparatus are known. The apparatus most likely included one set of paired asymmetric Pa elements, since left and right elements of these pairs may be distinguished. The $\mathrm{Pa}$ elements of Mashkovia display a platform morphology similar to many representatives of Polygnathus. On the other hand, the development of secondary keels and their shape strongly resembles $\mathrm{Pa}$ elements of the Frasnian genus Ancyrodella.

Mashkovia silesiensis $\mathrm{n}$. $\mathrm{sp}$.

(Plate 1, figs 1-8)

Derivation of name. From Silesia in southern Poland, where the species was found.

Diagnosis. Carminiplanate $\mathrm{Pa}$ element with distinct anterior margins developed as asymmetrical fixed blades; the right fixed blade typically with a prominent and very high posteriormost denticle; upper surface covered with nodes.

Holotype. the specimen illustrated in Plate 1, figs 1-2, GPIT $1792 / 1$.

Material. Seven Pa elements.

Type locality. WB-138 borehole, core sample at $250 \mathrm{~m}$, Upper Silesia, southern Poland.

Description. Platform triangular in outline, thick, slightly curved and arched in lateral view; anterior margins developed as parapets; right marginal parapet higher and composed of two to three fused denticles, the posterior-most of which is characteristically high; left marginal parapet composed of four to five fused denticles; free blade shorter than the platform, terminated gradually at distal end; anterior carina interrupted and positioned offset with respect to free blade; carina represented by widely spaced nodes; platform covered with nodes commonly arranged in longitudinal rows; adcarinal troughs very shallow.

Secondary keels wide and flattened, and slightly raised; secondary keel on the inner side tends to bifurcate; small basal cavity is shallow and square-shaped.

Remarks. Large, prominent denticle of the right marginal parapet of $M$. silesiensis sets this species apart from other species of the genus. The only other polygnathid conodont element with comparable developed, asymmetric parapets (or anterior margins) is the extremely rare species Tanaisognathus uralicus Kononova \& Pazuhin (in Aristov et al. 1983, p. 83, pl. 2, fig. 6). The latter, however, has a platform ornamented by strongly-marked transverse ridges.

Occurrence. Mashkovia silesiensis $\mathrm{n}$. $\mathrm{sp}$. is only known from the Middle expansa Zone of the eastern Upper Silesia (WB-138 borehole).

\section{Mashkovia simakovi (Gagiev, 1979)}

1979 Pseudopolygnathus simakovi Gagiev: 63-65, pl. 5, figs 1-9, pl. 7, figs 5-10.

1983 Mashkovia simakovi (Gagiev); Aristov, Gagiev \& Kononova: 79-80, pl. 1, fig. 4.

1984 Mashkovia similis (Gagiev); Chermnykh, Kononova, Pershina \& Cheusova: pl. 3, fig. 16 (only).

Diagnosis. Platform margins of the Pa element set with coarse nodes or short transverse ridges; anterior margins more or less symmetrical; adcarinal troughs well developed.

Description. Platform more or less symmetrical, triangular in outline, and arched in lateral view; anterior platform margins symmetrical, composed of two to three denticles fused into a raised ridge; free blade shorter than the platform, declining gradually into anterior carina; blade and carina form continuous, almost straight course; anterior carina consisting of small, obsolescent nodes; adcarinal troughs present throughout most of platform, bordered by strong marginal nodes or short transverse ridges. 


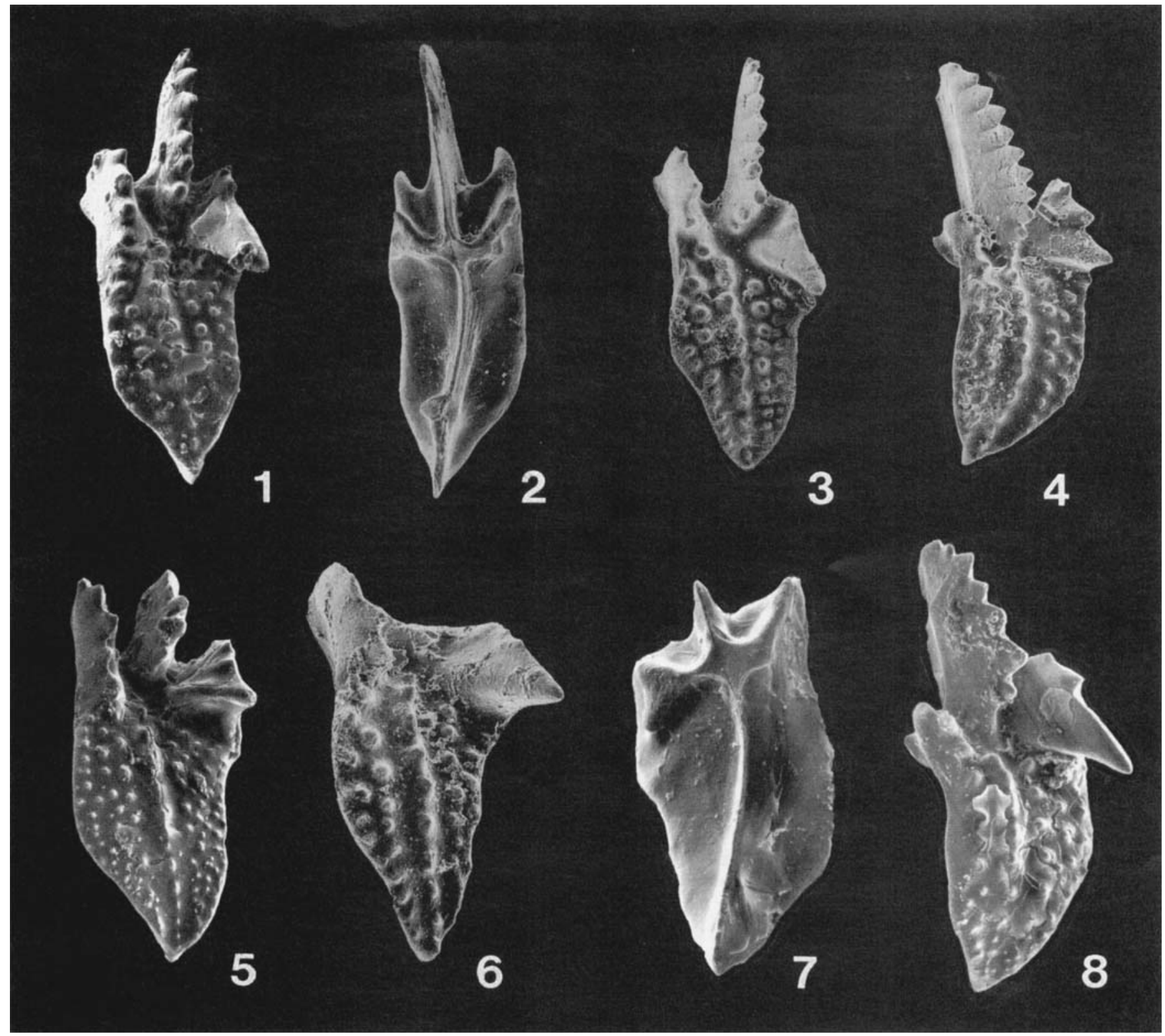

Explanation of Plate 1

Photomicrographs of late Famennian conodont elements of Mashkovia silesiensis n. sp. from the borehole WB-138, Upper Silesia, Poland. The numbers within brackets indicate the sample depth in metres. All figures are of Pa elements. figs 1-2, upper and lower views of holotype, SEM $\times 75$. GPIT 1792/1, (250); fig. 3, upper view of paratype, SEM $\times 75$. GPIT 1792/2, (250); fig. 4, oblique lateral view of paratype, SEM $\times 75$. GPIT 1792/3, (231); fig. 5, upper view, element with broken blade, SEM $\times 90$. GPIT 1792/4, (250); fig. 6, element with broken blade in upper view, SEM $\times 100$. GPIT 1792/5, (250); fig. 7, element with broken blade in lower view, SEM $\times 120$. GPIT 1792/6, (250); fig. 8, specimen in oblique lateral view, SEM $\times 90$. GPIT $1792 / 7,(238)$.

Pit of moderate size, diamond-shaped; two anteriorly directed, characteristically arched secondary keels meet pit at centre.

Remarks. There is a similarity between Mashkovia simakovi and $M$. tamarae in the overall form of the platform and in the character of the anterior platform margins. The latter species, however, differs from $M$. simakovi in having the platform ornamented with longitudinal rows of nodes. Furthermore, adcarinal troughs are not developed in the platform of $M$. tamarae.
Occurrence. Mashkovia simakovi is known from Novaya Zemlya and the Verkhoyansk region (Kolyma) of northeastern Asia (Fig. 3).

\section{Mashkovia similis (Gagiev, 1979)}

1979 Pseudopolygnathus similis Gagiev: 65-66, pl. 7, figs 11-13. 1983 Mashkovia similis (Gagiev); Aristov, Gagiev \& Kononova: 79, pl. 1, figs $1,2$.

1984 Mashkovia similis (Gagiev); Chermnykh, Kononova, Pershina \& Cheusova: pl. 3, fig. 17 (not fig. 16, M. simakovi). 
1988 Mashkovia similis (Gagiev); Aristov: 71-72, pl. 7, figs 8, 9. Diagnosis. Carminiplanate $\mathrm{Pa}$ element with a markedly asymmetrical platform; platform margins set with coarse nodes; right anterior platform margin consisting of fused, prominent denticles.

Description. Platform triangular in outline, markedly asymmetrical and curved; right (outer) platform margin higher than the left one, composed of up to three fused, prominent denticles, the posterior-most of which is the highest; adcarinal troughs characteristically present; platform bordered by strong marginal nodes; free blade about half the length of the unit, terminating abruptly at distal end; free blade and carina form continuous, gentle inward curvature; nodes of anterior carina small in comparison with denticulation of posterior carina.

Pit moderate to large; secondary keels wide and flattened. Remarks. Pa elements of Mashkovia similis can be distinguished from those of $M$. silesiensis on differences in the platform ornamentation and in the form of the anterior margins of the platform. $M$. similis differs from its ancestor Polygnathus bucerus by having a more asymmetrical platform, weaker ornamentation, a longer free blade, and, in particular, two secondary keels. $P$. bucerus is characterized by a large, expanded basal cavity.

Occurrence. Occurrences of Mashkovia similis are known from the Verkhoyansk region (Kolyma) of northeastern Asia, Novaya Zemlya, Timan-Pechora basin, eastern and western slopes of the southern Ural, and from the southeastern part of the East European (Russian) Platform (Fig. 3).

Mashkovia tamarae Kononova \& Pazuhin, 1983 1983 Mashkovia tamarae Kononova \& Pazuhin; Aristov, Gagiev \& Kononova: 80-81, pl. 1, fig. 8, pl. 2, figs 1, 2 (fig. 1, holotype). Diagnosis. Carminiplanate $\mathrm{Pa}$ element with a nearly bilaterally symmetrical platform; margins of the platform set with short ridges or coarse nodes; posterior platform ornamented with nodes.

Description. Platform triangular in outline, slightly curved and nearly bilaterally symmetrical; platform bordered by strong, short ridges or coarse nodes; anterior free margins are upturned and consist of fused, tapering denticles; short free blade terminates abruptly at its distal end; carina composed of small, widely spaced, discrete nodes; posterior half of the platform covered with small nodes; adult specimens show nodes arranged in longitudinal rows; adcarinal troughs not developed.

Pit very small, located in the junction of keel with secondary keels; two sharp, anteriorly directed secondary keels that do not reach the anterior tips of the platform.

Remarks. For comparison with Mashkovia simakovi, see under the latter.

Occurrence. Pa elements of Mashkovia tamarae has been found in the southern Ural and in the Verkhoyansk region (Kolyma) of northeastern Asia (Fig. 3).

\section{ACKNOWLEDGEMENTS}

The research on Devonian conodonts in Upper Silesia has been supported by the 'Deutsche Forschungsgemeinschaft' (Be 1296/ 3). This is a contribution to the German National Project 'Orogenic processes with particular reference to the Variscides' and to EUROPROBE. The Geological Enterprise, Cracow kindly allowed the author to sample the borehole WB-138. I am deeply indebted to Marzena Slupeczanska (Warsaw) for her help during the sampling and the assistance in this work. J. Nebelsick (Tübingen) and two anonymous reviewers are thanked for their helpful and constructive comments on the manuscript. I am also grateful to J. Neugebauer and B. Greiner (both Tübingen) for advice on matters of the Devonian palaeogeography. B. Waksmundzki of the Warsaw University drafted conodonts in Fig. 4. W. Gerber and H. Hüttemann (both Tübingen) provided technical assistance during the laboratory work.

\section{Manuscript received October 1996 Manuscript accepted January 1997}

\section{REFERENCES}

Aristov, V. A. 1988. Devonskie konodonty tsentral'nogo Devonskogo Polya (Russkaya Platforma). Akademiya Nauk SSSR, Geologicheskiy Institut, Trudy, 432: 1-119.

Aristov, V. A., Gagiev, M. H. \& Kononova, L. I. 1983. Filomorfogenez i stratigraficheskoe znachenie roda Mashkovia gen. nov. (Conodontophorida). Izvestia Akademii Nauk SSSR, seria geologicheskaiya, 2: 7283.

Balinski, A. 1995. Brachiopods and conodont stratigraphy of the Famennian from the Debnik anticline, southern Poland. Palaeontologia Polonica, 54: 3-88.

Belka, Z. 1995. Oberschlesisches Massiv - ein Terrane am Rande von Fennosarmatia und seine geodynamische Entwicklung. Terra Nostra, 95(8): 82.

Chermnykh, V. A., Kononova, L. I., Pershina, A. I. \& Cheusova, G. N. 1984. K charakteristike verkhnedevonskich otlozhenij reki Utinoj (Novaya Zemlya). Trudy Instituta geologii Komi filiala Akademii Nauk SSSR, 49: 23-33.

Gagiev, M. H. 1979. Konodonty iz pogranichnyh otlozhenij devona i karbona Omolonskogo massiva. 14th Tihookeanskij nauchnyj kongress, Magadan, 2: 1-104.

Glenister, B. F. \& Klapper, G. 1966. Upper Devonian conodonts from the Canning Basin, Western Australia. Journal of Paleontology, 40: 777-842.

Lewandowski, M. 1995. Palaeomagnetic constraints for Variscan mobilism of the Upper Silesian and Malopolska Massifs, southern Poland - reply. Geological Quarterly, 39(4): 283-292.

Matyja, H. 1993. Upper Devonian of Western Pomerania. Acta Geologica Polonica, 43(1-2): 27-94.

Narkiewicz, M. 1978. Stratigraphy and facies development of the Upper Devonian in the Olkusz-Zawiercie area, southern Poland. Acta Geologica Polonica, 28: 415-470.

Nawrocki, J. 1995. Palaeomagnetic constraints for Variscan mobilism of the Upper Silesian and Malopolska Massifs, southern Poland discussion. Geological Quarterly, 39(4): 271-282.

Perri, M. C. \& Spalletta, C. 1991. Famennian conodonts from Cava Cantoniera and Malpasso sections, Carnic Alps, Italy. Bolletino della Società Paleontologica Italiana, 30: 47-78.

Sandberg, C. A. \& Ziegler, W. 1979. Taxonomy and biofacies of important conodonts of Late Devonian styriacus-Zone, United States and Germany. Geologica et Palaeontologica, 13: 173-212.

Savoy, L. E. \& Harris, A. G. 1993. Conodont biofacies and taphonomy along a carbonate ramp to black shale basin (latest Devonian and earliest Carboniferous), southernmost Canadian Cordillera and adjacent Montana. Canadian Journal of Earth Sciences, 30: 2404 2422.

Sweet, W. C. 1988. The Conodonta: Morphology, Taxonomy, Paleoecology, and Evolutionary History of a Long-Extinct Animal Phylum. Clarendon Press, Oxford.

Szulczewski, M., Belka, Z. \& S. Skompski. 1996. Stop 6. Ostrowka quarry. In Szulczewski, M. \& Skompski, S. (Eds) Sixth European Conodont Symposium (ECOS VI), Excursion Guide, 42-49. Institut Paleobiologii PAN, Warsaw.

Ziegler, W. 1962. Taxonomie und Phylogenie oberdevonischer Conodonten und ihre stratigraphische Bedeutung. Abhandlungen des Hessischen Landesamtes für Bodenforschung, 38: 1-166. 